\title{
ナノC/Cコンボジット
}

\section{Nano-C/C composite materials}

\section{沖野不二雄 ${ }^{* *}$, 太田道也 ${ }^{* *}$}

Fujio Okino** and Michiya Ota**

\begin{abstract}
Carbon fiber reinforced carbon (C/C) composite materials with low density, high specific strength and elastic modulus, high ablation property, high frictional and wear properties have been used in the field of aerospace engineering and vehicle industry. Further improvement in their manufacturing processes and brittle properties are requested as one of the most promising advanced composite materials. Mechanical and other properties should be improved by controlling the microstructures in carbon fiber and matrix carbon and their interfacial properties. In the meantime, a series of nanocarbon materials represented by fullerenes and carbon nanotubes began to be regarded as future advanced high performance materials since their discovery before and after 1990. Nanocarbon reinforced plastic composites are also reported as new nanoscaled composite materials with controlled microstructures and interfacial properties. Carbonized composite materials with nanocarbons are, therefore, expected to possess improved mechanical strength, fracture behavior, frictional and wear properties, electrical conductivity, and thermal properties. Here we review the preparation and properties of nanocarbon reinforced carbon composite materials with our recent proposals concerning the nano-C/C composite materials.
\end{abstract}

\section{KEYWORDS : C/C composite materials, Carbon nanotube, Microstructures, Interfacial properties, Nano- $\mathrm{C} / \mathrm{C}$ composite materials}

\section{1.はじめに}

炭素材料は結合様式, 構造, 組織などの多様性から,ささざまな 形状をとり,かつまた機械的性質や電気・熱伝導性, 耐薬品性, 而 酸化性などにおいて幅広い特性を示す。この炭素材料を母材と して, その強度や耐衝撃性などを改善する目的で1960年代に炭 素繊維強化炭素複合材料 (以下, C/C コンポジットとする)が開発 された。その結果, 炭素瀻維との複合化によって, 比強度・比弾 性率が高温でも減衰しない, 耐衝撃性に優れている, 熱膨張係数 が小さいなどの諸特性が炭素材料に付与され, 耐熱, 摩擦, 構造, 生体材料として注目されている。開発された当初のC/C コンポ ジットはロケットノズルや航空機のブレーキなどの航空宇宙用分 野への応用が中心であったが, 製造期間やコストなどの技術的問 題の改善や工業材料としての新しいニーズのもとで今日では摩 擦材料, アブレーション材, タービンブレード, 断熱材保護板など の耐熱材料, 半導体用 $\mathrm{Si}$ 単結晶の引き上げ装置の部材や高温処理 用炉の部材, ガラス製造用部材, ボルト,ナットなどの構造材料, 人工骨, 股関節などの生体材料にも応用されている1)。しかしな がら, 製造工程の簡素化, 機械的強度の改善などの課題も残され ている2)。

一方で, 1990 年前後にフラーレン3)やカーボンナノチューブ4)
ナノファイバー5) という新しい形態の炭素材料が発見され，これ らが引き金となってナノカーボンマテリアルという, きわめてフ アインであるが未来的な可能性を秘めた新しい分野が展開され るようになった6)。すなわち, 炭素材料の構造制御 1つをとって もそれまでのミクロスケールからナノスケールにまで,一気に分 子レベルのオーダーで炭素材料の多様性を捕らえ, これをボトムア ップでマクロな構造材料にまで設計することができるようになっ た。しかし, 従来の炭素材料でも活性炭あるいは活性炭素繊維の 細孔径に関する議論はすでにナノスケール以下のレベルである。 活性炭の細孔径 $(w)$ は, $w<2 \mathrm{~nm}$ でミク口孔, $2 \mathrm{~nm}<w<50 \mathrm{~nm}$ で メソ孔, $w>50 \mathrm{~nm}$ でマクロ孔と分類されて, 細孔径の分布によっ て活性炭の比表面積を評価している。また, 層間化合物の面間距 離の問題も同様で, 黒鉛では $0.3354 \mathrm{~nm}$ の層間が金属原子などの 化学種の挿入によってそれよりも面間距離が広がる。こうした 従来の分野にもナノスケールの概念を導入することで構造設計 が展開され，新しい多孔質炭素の調製技術が報告されている7)。

このように従来のバルクな性質とは異なり,ナノスケールにま で制限されてくると予想のつかない新しい性質が現れることが 1959年R.ファインマンによって予測されている8)。例えば, カー ボンナノチューブ (Carbon nanotube, CNT) の機械的強度は黒鉛 と同じ構造欠陥のきわめて小さいグラフェン層から構成されて

* 信州大学繊維学部素材開発化学科: $=386-8567$ 長野県上田市常田3-15-1

* Department of Materials Chemistry, Faculty of Textile Science \& Technology : 3-15-1 Tokida, Ueda, Nagano 386-8567, Japan

** 群馬工業高等専門学校物質工学科 : $=371-8530$ 群馬県前橋市鳥羽町 580

** Department of Chemistry, Gunma College of Technology : 580 Toriba-machi, Maebashi, Gunma 371-8530, Japan 
いるので非常に大きな值が期待されている9)。また，表面活性が 高いことから環境・エネルギー, エレクトロニクスなどの分野で 新材料として脚光を浴びている10)。

このようなナノカーボンの諸特性を複合材料として利用する 研究が, 近年報告されつつある。すなわち, 複合材料の組織, 炭素 繊維表面の構造, 母材の微細構造などをナノスケールで捕えるこ とで機械的強度, 熱および電気的性質の向上が期待される11)。

そこで, 本稿では C/Cコンポジットの製法に注目しながら,ナ ノカーボン, 特にCNTを同時に混合させてつくるカーボンナノチ ユーブ/炭素纎維／炭素複合材料（以下, CNT/C/C コンポジッ トと略記する）の製法について最近の報告をもとにまとめるこ ととする。

\section{C/C コンポジット}

\section{1 原料系とコンポジットの作製}

炭素繊維で強化する複合材料には母材をポリマーのままで使 用する炭素繊維強化プラスチック (Carbon fiber reinforced plastic, CFRP) があるが, C/C コンポジットは母材が高温処理されて炭素 化もしくは黒鉛化されることから, 製造にあたっては炭素化のため の高温処理工程が増えることでより複雑になる。

さらに母材の炭素前駆体はこの高温処理工程で熱分解して容 積が減少するために, 炭素繊維間に隙間が生ずる。したがって, C/Cコンポジットの製造では炭素繊維間の隙間ができる限り発生 しないための工夫が必要である。その際には, 単に物理的な充填 だけでなく炭素繊維と母材炭素との間の適当な化学結合も考慮 されなければならない。

C/Cコンポジット作製にあたっては使用する炭素繊維の選択が 第一で, 次に母材炭素の充填法の選択が続く。炭素繊維は, 短繊 維と長繊維の 2 種類あるがさらにTable 1 に示すように原料系や機 械的強度によっても分類される12)。

また, 炭素繊維は一軸配向の強い異方性をもたらすことから, 必要とされる等方性の程度に応じて二次元配向として平織, 綾織, 朱子 (繻子) 織などの織布を積層したり, あるいは三次元配向と して立体織が使用される(Fig.1, Fig.2) 13)。

Table 2 にC/Cコンポジット作製法と原料系を示す13)。一般に $\mathrm{C} / \mathrm{C}$ コンポジットの製造は母材炭素となる原料有機前駆体を含浸 させたのちに加熱炭素化する方法 (含浸法) とガス状低分子有機 化合物を熱分解して母材とする方法 (CVD法) に大別されるが,

Table 1 Classification of carbon fibers.

\begin{tabular}{l|l}
\hline Precursor fiber & $\begin{array}{l}\text { Rayon, Polyacrylonitrile (PAN), Pitch, } \\
\text { Vapor grown carbon fiber(VGCF) }\end{array}$ \\
\hline Grade of carbon fiber & Carbon grade, Graphite grade, Activated grade \\
\hline Mechanical performance & $\begin{array}{l}\text { General purpose grade (GP) } \\
\text { High performance grade (HP) }\end{array}$ \\
& $\begin{array}{l}\text { Ultra high elastic modulus type (UHM) } \\
\text { High elastic modulus type (HM) } \\
\text { Intermediate elastic modulus type (IM) } \\
\text { Standard elastic modulus type (HT) } \\
\text { Low elastic modulus type (LM) }\end{array}$ \\
\hline
\end{tabular}

有機前駆体の含浸では炭素化に伴う炭素化収率が低いためにピ ッチを使用して炭素化収率を高くしたり, 数回に分けて含浸をく り返して母材を緻密化し嵩比重を上げる必要がある。オートク レーブ中で加圧下炭素化を行うこともあるが, この場合には炭素 化収率の増加や樹脂含浸工程数を削減できる。また, 含浸法と CVD法の両方を複合させることもある ${ }^{13 b)}$ 。CVD法は原料有機 前駆体の熱分解過程と母材炭素の生成過程が同時に進行する方 法であるが, 含浸法では有機物の熱分解の際に気孔の発生と母材 の収縮が伴う。気孔の発生はコンポジットの強度の低下につな
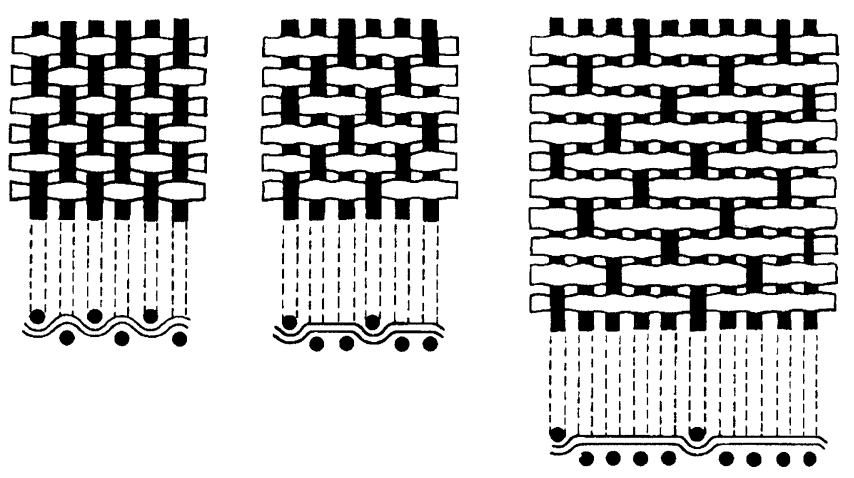

plain weave twill weave

satin weave

Fig.1 Carbon fiber weave styles for composite materials ${ }^{13 a)}$.

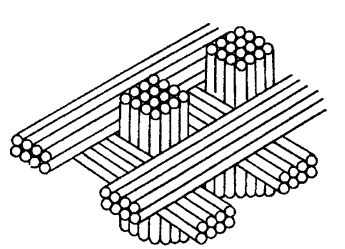

(a)

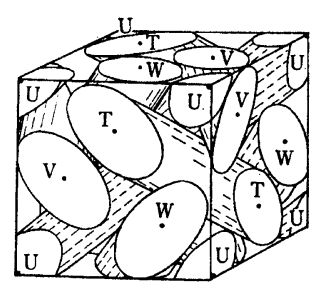

(b)

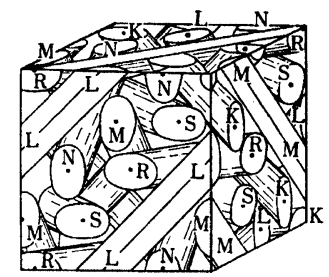

(c)

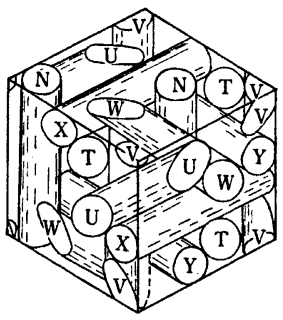

(d)
Fig.2 Various dimensional carbon fiber textiles ${ }^{13 b)}$. (a) : 3D, (b) : 4D, (c) :6D, (d) : 7D

Table 2 Manufacturing of $\mathrm{C} / \mathrm{C}$ composites.

\begin{tabular}{l|l|l}
\hline Procedure & Matrix as a precursor & Materials \\
\hline \multirow{2}{*}{$\begin{array}{l}\text { Impregnation and } \\
\text { Carbonization }\end{array}$} & Thermoplastic resins & Pitch \\
\cline { 2 - 3 } & Thermosetting resins & $\begin{array}{l}\text { Phenolic resin, Epoxy resin, } \\
\text { Furan resin, Polyphenylene, } \\
\text { Polyimide }\end{array}$ \\
\hline $\begin{array}{c}\text { Chemical Vapor Deposition } \\
\text { (CVD) }\end{array}$ & Hydrocarbon gases & Methane, Propane, Benzene \\
\hline
\end{tabular}


がることが懸念され，母材の収縮は熱硬化性樹脂の場合に亀裂の 発生につながることが予想される。一方で, 母材の収縮に伴って 応力黒鉛化による炭素網面の配向が期待できる。このように母 材炭素の組織は C/C コンポジットの強度と関係があり, 原料有機 物前駆体の種類や熱処理温度によって,そしてまた繊維の存在や 繊維表面の構造と官能基の存在によって大きく影響を受けるこ とが知られている13c)。そこで, 以下では含浸法について述べる。

\section{2 母材炭素の組織}

母材炭素と炭素繊維との相互作用は C/Cコンポジットの性質 に大きな影響をもたらす。ピッチを用いて加圧下炭素化をした 場合には, 圧の程度によって炭素繊維近傍での炭素網面の配向に 違いが見られることが報告されている14)。加圧下で炭素化しな い場合には繊維束間で流れ組織が形成されて層間剪断強度が低 下することが観測されており，それを改善するためには黒鉛粉末15) やカーボンブラック 16)などの添加による組織制御が効果的であ る。また, 熱硬化性樹脂でも炭素繊維との相互作用が報告されて いる。一般に, 熱硬化性樹脂はそれのみを炭素化処理した場合に はガラス状炭素になるが, 炭素繊維の存在で繊維の近傍で配向性 が現れ，処理温度が $1000{ }^{\circ} \mathrm{C}, 2200^{\circ} \mathrm{C}, 2800{ }^{\circ} \mathrm{C}, 3000{ }^{\circ} \mathrm{C}$ と高くなるに 従って光学的異方性領域が炭素繊維と一体化して黒鉛化する。 この黒鉛化機構は応力黒鉛化と呼ばれている17)。近年, プリフォ ームドヤーン18)を用いる方法や自己焼結性コークスを母材炭素 の前駆体とする方法が報告されており ${ }^{19)}$, 高い炭素化収率と高い 機械的強度が得られることに加えて製造工程の短縮化をはかる ことができるようになった。

\section{3 炭素緎維の表面処理と母材炭素との接着性}

炭素繊維表面は通常サイジング剤が塗布されているが, 基本的 にコンポジットとして $1000{ }^{\circ} \mathrm{C}$ 以上の高温下で炭素化処理される 場合にはそれほど大きな影響は報告されていない。しかし, 炭素繊 維表面のカルボキシル基 (-COOH), カルボニル基 $(>\mathrm{CO})$, 水酸基 (-OH) などの含酸素基の存在は母材炭素の前駆体との接着性に おいて重要な影響を及ほすことが報告されている。炭素繊維の 表面処理は Table 3 に示すように, 一般に, 酸化, エッチング, コ ーティングおよびグラフトの方法がとられるが, それらの方法に よってCFRPの剪断強度に及ぼす影響が異なることがわかる22)。 このことから, 炭素繊維の表面処理が母材炭素の前駆体との接着 性に影響することがわかる。

したがって, C/Cコンポジット調製のための炭素化ならびに黒 鉛化処理において表面処理の効果が出てくると予想される。実 際にFig.3ならびにTable 4 に示すように, 高温での加熱処理で曲

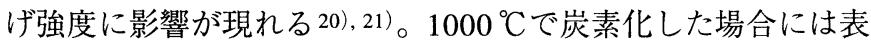
面処理した炭素繊維を使用したほうが曲げ強度は低くなり， $3000{ }^{\circ} \mathrm{C} て ゙$ 黒鉛化処理した場合には表面処理した炭素繊維を使用 したほうが曲げ強度は高くなる20)。この場合, 炭素化処理では亀 裂は母材炭素から発生すると考えられ, 炭素繊維の強度を有効に 利用するには母材と炭素繊維との接着強度は適度に低いほうが よいと考えられる。また, 炭素化処理前の炭素繊維と母材炭素前 駆体との接着性は母材炭素の微細組織に強く影響し, 2400〜
Table 3 Effect of surface treatment of carbon fibers on ILSS of C/C composites 22 .

\begin{tabular}{c|c|c}
\hline Surface treatment & Chemicals & Improvement in ILSS (\%) \\
\hline Gaseous oxidation & air, ozone, $\mathrm{RF}$ plasma & $10-15$ \\
Liquid phase oxidation & $\mathrm{HNO}_{3}, \mathrm{NaClO}$, electrolytic & $100-200$ \\
Whiskerization & $\mathrm{Si}_{3} \mathrm{~N}_{4}, \mathrm{TiO}_{2}, \mathrm{SiC}$ & $200-300$ \\
Pyrolytic carbon coating & $\mathrm{CH}_{4}, \mathrm{FeC}, \mathrm{SiC}$ & $60-100$ \\
Polymer grafting & & $80-100$ \\
\hline
\end{tabular}

ILSS : Interlaminar shear strength

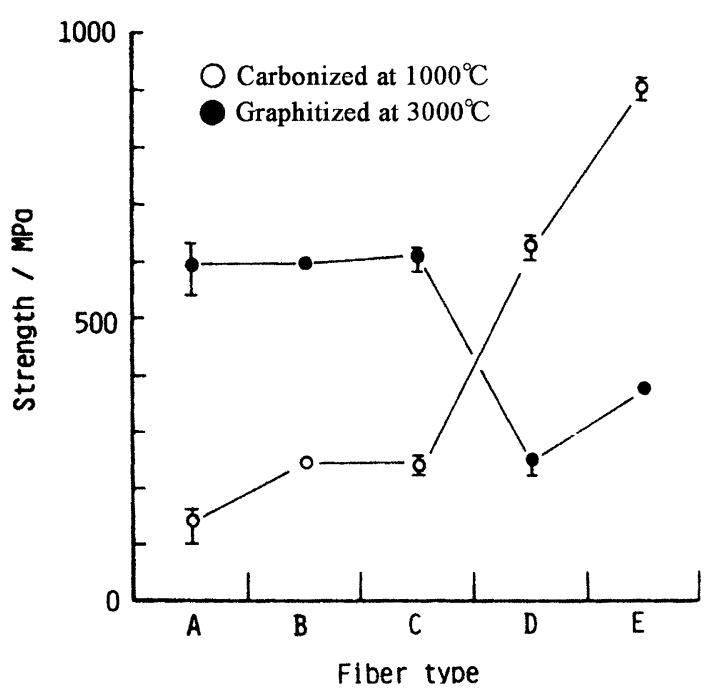

Fig.3 Flexural strength of $\mathrm{C} / \mathrm{C}$ composites with different carbon fibers $^{20)}$. Symbols A - F are given in Table 4.

Table 4 Types of carbon fibers used for C/C composite materials $^{20)}$.

\begin{tabular}{c|c|c|c}
\hline Fiber type & Fiber* & Surface treatment & Sizing agent \\
\hline A & M40 90 & Yes & No \\
B & M40 50A & Yes & Yes \\
C & M40 40B & Yes & Yes \\
\hline D & M40 99 & No & No \\
E & M40 59 & No & Yes \\
\hline
\end{tabular}

Carbon matrix : Furan resin-derived carbon,

*M40 : High modulus carbon fiber

$3000{ }^{\circ} \mathrm{C}$ 高温処理で光学的異方性領域の発達に影響が現れる21)。 近年, $\mathrm{C} / \mathrm{C}$ コンポジットへの関心が高まるにつれて炭素繊維の 表面処理に関する報告が増えている22)-26)。傾向としては, 取扱 いが容易なプラズマ処理が多く見受けられる23a)-f)。プラズマ処 理の場合, 炭素繊維の種類によって導入される官能基に違いが見 られ, ポリアクリロニトリル (PAN) 系ならびにピッチ系炭素繊維 について $1 \mathrm{~W}$ 未満の低出力プラズマ (ガス䨌囲気： $\mathrm{NH}_{3}, \mathrm{~N}_{2}$, 空 気，アルゴン)で表面処理を行ったところ23a),b), 空気の効果は 


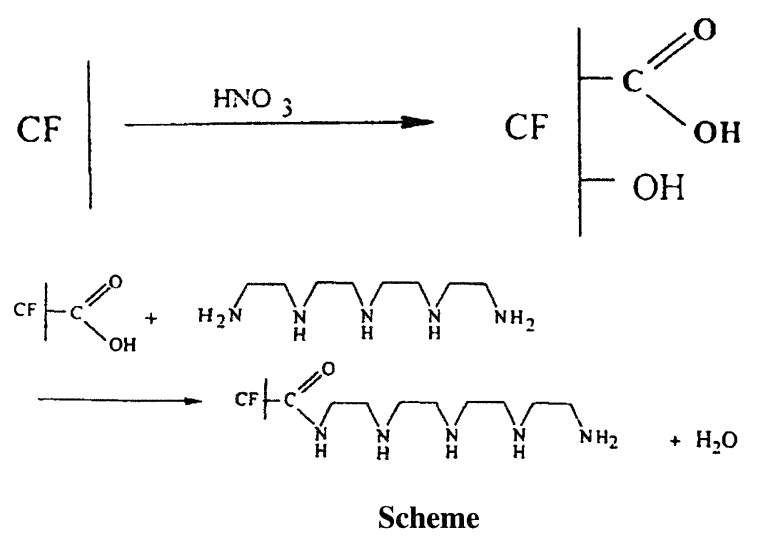

$\mathrm{NH}_{3}$ や $\mathrm{N}_{2}$ ガスに比べて最も反応性が高く, PAN系炭素繊維では 表面にカルボキシル基 $(-\mathrm{COOH})$ とヒドロキシル基 $(-\mathrm{OH})$ が生 成したがピッチ系にはーOH基のみが生成した。ただし, $\mathrm{NH}_{3}$ と $\mathrm{N}_{2}$ ガスプラズマで生成するアミノ基 $\left(-\mathrm{NH}_{2}\right)$ とイミン基 $(>\mathrm{C}=\mathrm{NH})$ は空気中に出すとすぐに-OH 基で置換され不安定であった。炭 素纎維表面のアミノ基はエポキシ樹脂との接着性向上には適し ているので表面処理した炭素繊維を空気中に取り出すことなく 不活性雲囲気中で樹脂含浸すれば効果的であると考えられる。

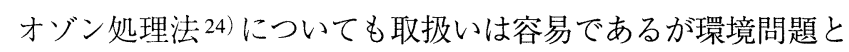
の関係も視野に入れる必要が出るかと懸念される。しかし, 興味

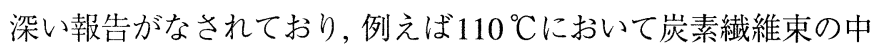
を4\%のオゾンを流して8 時間の表面処理を行ったところ, 纎維 表面は軸方向に細かな溝が生成し,それに伴って比表面積は増加 したが顕著な強度低下は見られなかった。繊維表面には-COOH

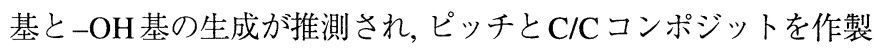
したところ, 繊維と母材との界面における接合は強くなり, 黒鉛

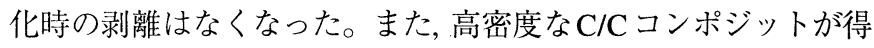
られ, 特にピッチ系繊維を用いると繊維と母材との界面の識別が 困難なくらい一体化し, 開気孔も観察されて再含浸が可能である とわかった24a)。

固相一液相反応であるが, 有機化学的なカップリング反応や Diels-Alder 反応を利用する表面処理法についても報告がなされ ている25),26)。

カップリング反応は Schemes $(1)$ （2)に示した反応で, $100 \AA$ 当たり 2.4 個の酸性基が導入され，そのうち $52 \%$ (カルボキシル 基として) がテトラエチレンペンタアミン（TEPA）と反応し, $48 \%$ がフェノール性のヒドロキシル基であった。TEPA との反応によ って $100 \AA$ 当たり 5.6 個のアミノ基が存在することがわかった。 この酸化過程で炭素䋊維の比表面積も増加し, Fig.4に示すよう な酸化機構が提案されている。またFig.5に示すようにテトラシ アノエチレン $(\mathrm{TCNE})$ や無水マレイ酸はDiels-Alder 反応によっ て炭素繊維にシアノ基やケトン基などを導入した25b)。

炭素繊維に対して電気化学的手法で表面処理を行う方法26)も あるが, いずれにしても母材炭素前駆体との接着性を向上させる ために含酸素基や含窒素基の効率良い導入が必要であると考え られている。

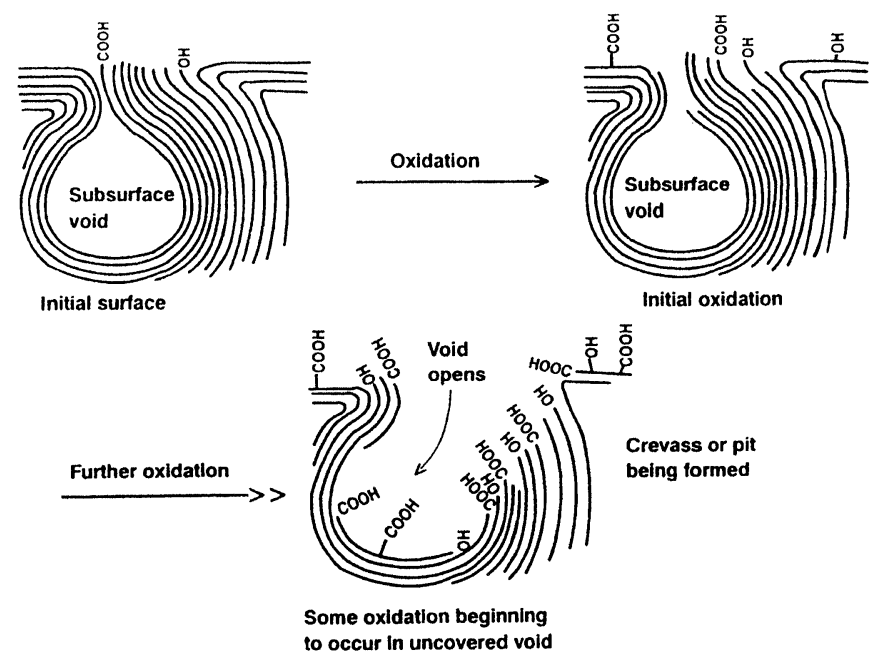

Fig.4 Introduction of acidic functional groups during nitric acid oxidation of carbon fiber surfaces which causes an increase in specific surface area ${ }^{25 a}$.

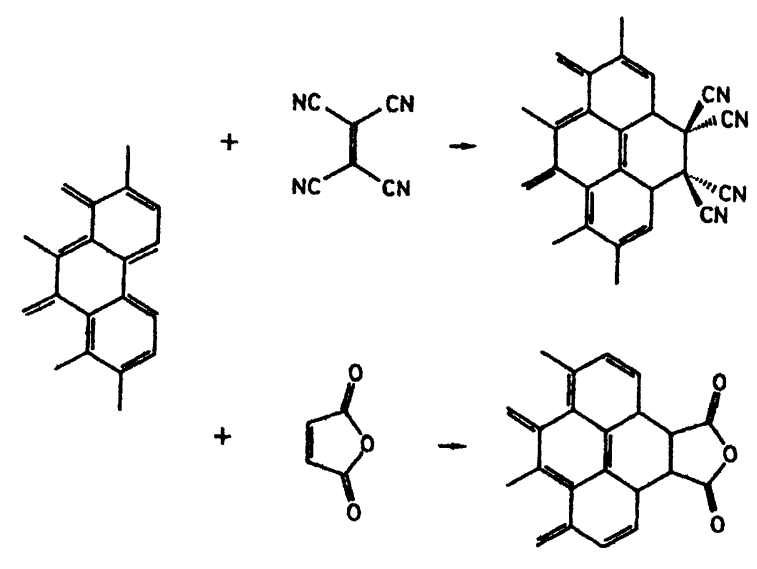

Fig.5 Diels-Alder reactions on the surface of carbon fibers ${ }^{25 b}$ ).

\section{3. カーボンナノチューブ（CNT）}

1985 年にKroto, Smalley, Curl らによってフラーレンが発見され3), フラーレンの合成の際に発生する炭素生成物の中から 1991 年に 飯島によって(多層) カーボンナノチューブ4) が発見された。そ の後, カーボンナノチューブは単層カーボンナノチューブ (Singlewalled carbon nanotube, SWCNT) 27) と多層カーボンナノチュー ブ (Multi-walled carbon nanotube, MWCNT)に分類されている (Fig.6)。CNTの性質は興味深く, カーボンナノチューブは黒鉛 と同じ構造欠陥のきわめて少ないグラフェン層の筒から構成さ れており理想的構造である。したがって非常に高い機械的性質 が期待できる。しかし, 実際の測定結果は報告者によってバラつ き, 例えば引張強度と弾性率はSWCNT で $1 \mathrm{GPa}$ と 49〜77 $\mathrm{GPa}^{28)}$, MWCNTで11〜63GPa と270〜950GPa ${ }^{29)}$ と測定されている。 また, フラーレンはトルエンなどの溶媒に可溶であるが, CNTは ほかの炭素同素体と同様に溶媒には不溶である。そこで, SWCNT の末端を酸処理でカットして,そのエッジ部に生成したカルボ キシル基とオクタデシルアミンなどをカップリング反応させたと 


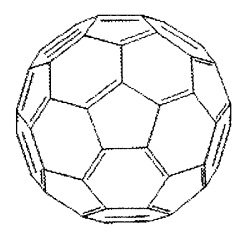

Fullerene

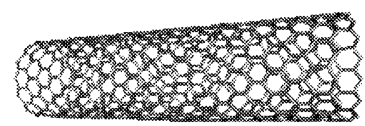

Single-walled carbon nanotube

(SWCNT)

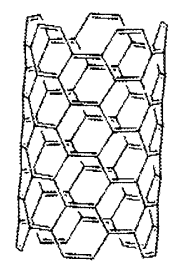

Carbon nanotube

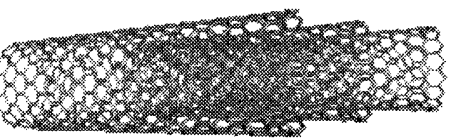

Multi-walled carbon nanotube

(MWCNT)
Fig.6 Structures of fullerene and CNTs.

ころ, SWCNTは溶媒に均一分散して可溶化することが報告され ている30)。電気特性は, シートの巻き方 (カイラリティー)によ って, 半導体から金属まで電気伝導性が変化することが知られて いる31)。

一方, チューブラータイプのCNT 以外にも気相成長炭素繊維 (VGCF), プレートレットタイプに代表されるカーボンナノファ イバーや,カーボンナノホーン,ヘリングボーンタイプの新しい形 状のナノカーボンが調製されている31b),c)。

\section{4. カーボンナノチューブの合成 ${ }^{32)}$}

カーボンナノチューブの合成は, 大雑把ではあるが「アーク放 電法」,「レーザーアブレーション法」,「化学気相成長 (CVD) 法」 の3種類に分類される。いずれもフラーレンの合成法に類似の手 法である。この分野はまだわずか 15 年しか経過していないにも かかわらず, 幅広い分野で多数の報告がなされていてすべてを捕ら えるのは困難である。そこで, 以下にC/Cコンポジットに関係し てくると思われる内容を選択してごく簡単にそれらの方法を説 明する。

\section{1 アーク放電法4), 33)}

2 本の黒鉛電極を数 $\mathrm{mm}$ 程度まで近付けた状態でアーク放電を 行わせる方法であるが, 㓌極側に付着するススにフラーレンなどと 一緒にカーボンナノチューブが含まれている。MWCNTは触媒 がなくても生成するが, SWCNTの生成には触媒が必要である。 触媒には鉄, コバルト, ニッケル, パラジウム, ロジウム, 白金なら びにイットリウム, ランタンなどが使用されて, 陽極側の黒鉛電 極に触媒を含有させておく方法がとられる。

\section{2 レーザーアブレーション法 ${ }^{34)}$}

$1200{ }^{\circ} \mathrm{C} に し た$ 横型管状炉中にコバルトやニッケルを数\%程度 含有する黒鉛棒を入れておき, パルスレーザーをその黑鉛棒に照射 して炭素と触媒金属を瞬時に蒸発させて束になったSWCNTを 生成する方法である。MWCNTを合成する場合には触媒は不要 である。

\section{3 化学気相成長 (CVD) 法 35a), 36)}

鉄, コバルト,ニッケルなどの触媒の存在下でメタンやエチレン, アセチレン, ベンゼンなどの炭化水素を 550 ～ $1200{ }^{\circ} \mathrm{C}$ のいずれか の温度において熱分解する方法で, 気相成長炭素纎維の合成と同 じ手法である。Bakerらや遠藤らは1970年代にそれぞれCVD法 でチューブ状炭素ナノフィラメントをすでに報告しているが, 当 時カーボンナノチューブとしての脚光は浴びていない5), 37)。シ リコンウエハー上に疎らに敷いておいたミクロンオーダーの触媒 微粒子に, 炭素源としてメタンガスを $850 \sim 1000{ }^{\circ} \mathrm{C}$ で供給すると 纎維径の細いSWCNTが得られたとの報告がある38)。最近, 水蒸 気の存在下で不純物の存在しない配向性に優れたSWCNTが合 成されている35b)。

上述した4.1〜4.3のカーボンナノチューブの合成では，アー ク放電法は結晶性の高いMWCNTの合成に適し,レーザーアブレ ーション法は高純度のSWCNTの合成に, CVD 法は大量合成と 基板への成長にそれぞれ適していると言われている。

\section{4 触媒成長 CVD (CCVD) 法}

大量生産に適している方法はCVD法であるが, 触媒金属粒子 の粒子径, 粒度分布, 基板上へのセッティング, 無定形炭素などの 析出の問題がある。1990年代後半からメタロセンを使ったCVD 法によるカーボンナノチューブの生成が行われるようになった39)。 メタロセンはフェロセン $\left(\mathrm{C}_{5} \mathrm{H}_{5}\right)_{2} \mathrm{Fe}$ に代表される分子で, 加熱に よって $160 \sim 200{ }^{\circ} \mathrm{C}$ 程度で昇華して $580 \sim 700{ }^{\circ} \mathrm{C}$ 付近で熱分解す ることが知られている。したがって, 気化して分解することで遊 離する $\mathrm{Fe}$ は小さいクラスターレベルとなり, 金属粒子の抱える問 題を改善することができる。

フェロセンを用いたカーボンナノチューブの代表的な合成装置 をFig.7に示す 39k)。基本的には, A B B (電気炉I) でフェロセン と炭化水素を気化させて, それを高温の電気炉II まで送り込んで 熱分解させる方法である。このとき, 電気炉II の石英管内壁また は基板 (C) や炉の外にある捕集用器 (D) にカーボンナノチュー ブなどが析出してくる。生成するナノチューブは配向性に優れ ているが, 副生成物も同時に混入してくる。新しい手法として, アルコールとフェロセンの混合蒸気を気相熱分解してSWCNTを 生成する方法が開発されている35c)。

4.1〜4.4で代表的な合成法を見たが, 材料としてカーボンナ ノチューブを使用するには，(i) 安価で純度の高い大量合成法の 確立, (ii) 直径と長さやカイラリティの制御, (iii) チューブの配 向性と生成位置の制御などの問題を改善しなければならない。こ うした問題点を改善する1つの方法として, テンプレート法など が開発されている。テンプレート法40)では, メソポーラスシリカ や酸化アルミニウム, ゼオライトなどが使用されており, CNTの 配向性や長さの制御が可能であるが大量生産などに課題が残さ れている。また, 有機金属化合物の熱分解反応 $39 \mathrm{e}), 41)$ により基板 上に高配向のCNTを析出させる方法 (Fig.8, Fig.9）も報告され ている。

カーボンナノチューブでは, (1)走査型プローブ顕微鏡の探針 42), (2)燃料電池や電気二重層キャパシ夕の電極 43), (3)水素吸蔵材 ${ }^{44)}$, 


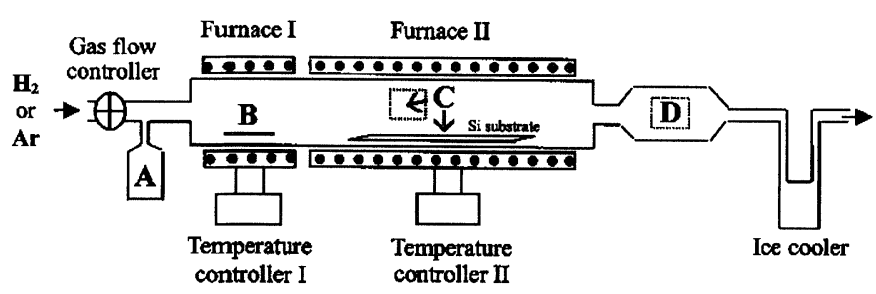

Fig.7 Schematic diagram of the apparatus used for the synthesis of CNTs. (A) and (B) : vaporization sources ; (C) : deposition on $\mathrm{Si}$ or quartz glass substrate, (D) : room-temperature deposition on a normal glass surface ${ }^{39 k}$.
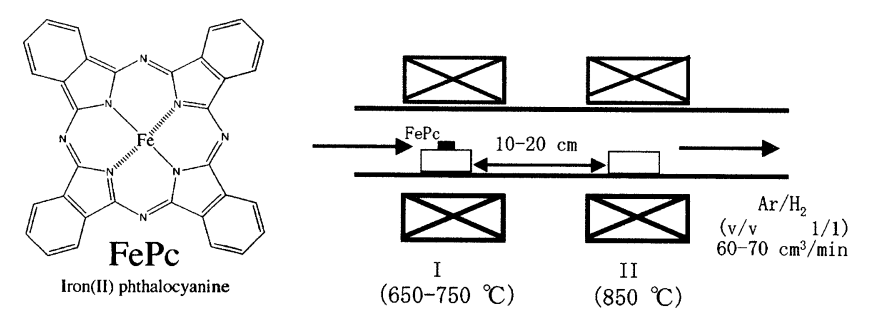

Fig.8 Schematic diagram for the synthesis of CNT ${ }^{39 e}$ ).

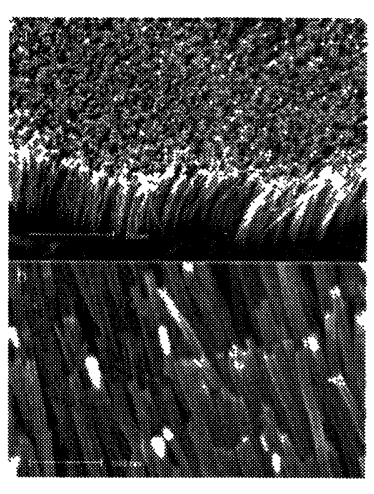

$\left(\mathrm{II}: 850^{\circ} \mathrm{C}\right)$

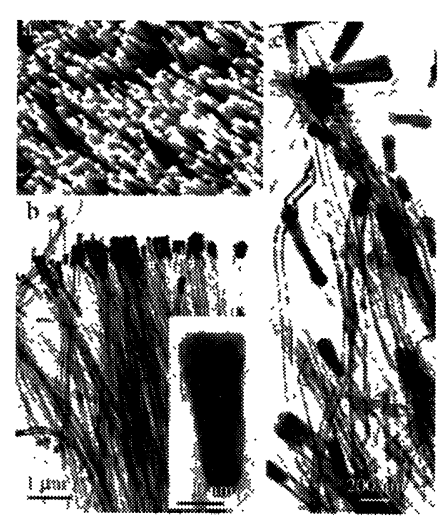

(II: $900^{\circ} \mathrm{C}$ )
Fig.9 SEM and TEM images of the products ${ }^{39 e}$ ).

(4)複合材料 11), 45), (5)集積回路 (IC) 46), (6)フィールド・エミッシ ヨン・ディスプレイ (FED) の電界放出 ${ }^{47)}$, (7)医療材料48b)などへ の応用が検討されている。いずれの用途を考えても上述した (i) 〜 (iii)の課題を改善する必要がある。

\section{5. ナノC/C コンポジット}

これまでにC/Cコンポジットにおいて炭素繊維と母材炭素と の界面における接着性の重要性はすでに述べた。この改善策と して炭素䋐維の表面処理, 母材炭素前駆体の種類や加熱処理温度, 加圧下炭素化などの熱処理工程の改善, 添加剤による微細組織の 制御などが検討されている。一方では, カーボンナノチューブの ようにナノスケールの材料に関する研究が活発に行われており, 軸方向への引張り応力に対しては繊維径が細くなって一炭素原 子列まで塑性変形をするネッキングを起こすことが理論的に予 測されている。また, 曲げ応力に対してはうねり構造をとりながら 変形することが予測されている48a)。この新しい炭素材料をこれ
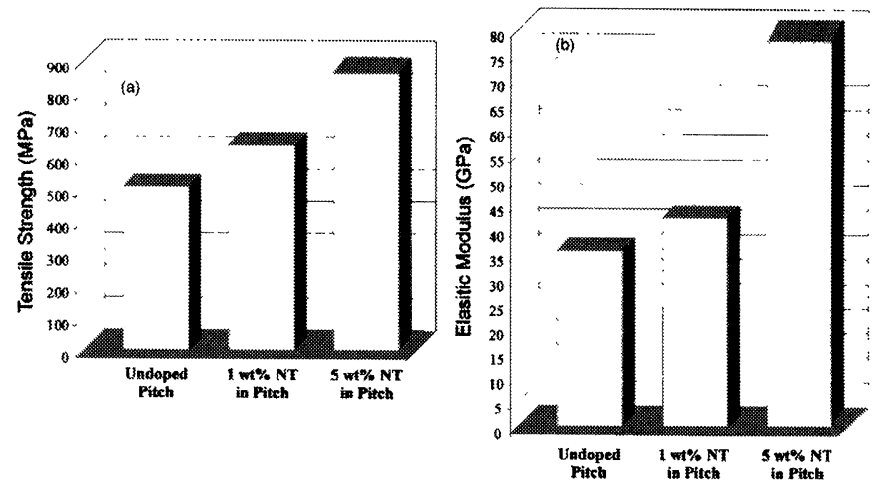

Fig.10 A comparison of the tensile strength (a) and modulus (b) of composite carbon fibers with 1 and $5 \mathrm{wt} \%$ nanotube loadings to the corresponding values in unmodified isotropic pitch fibers ${ }^{50)}$.

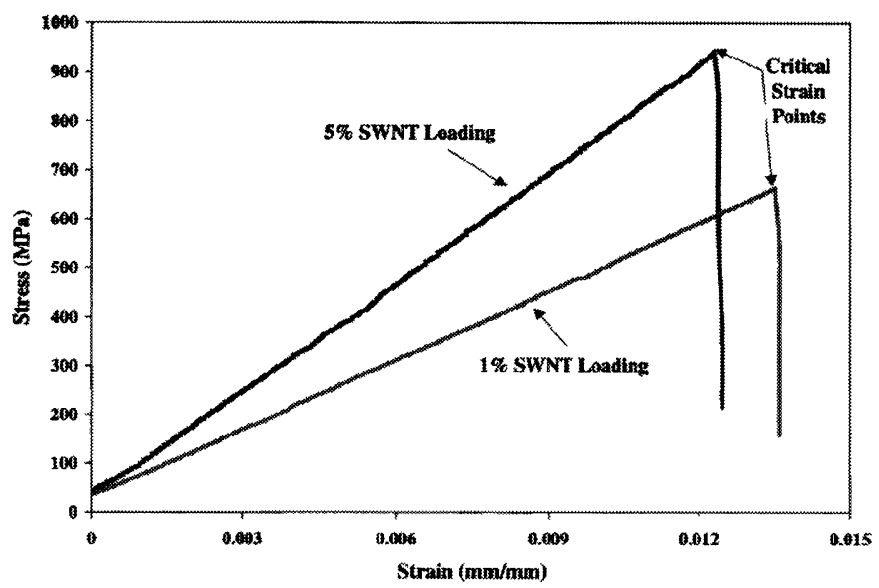

Fig.11 Typical stress-strain plots for composite carbon fibers with 1 and 5 wt $\%$ CNT loadings ${ }^{50)}$.

までのC/Cコンポジットに複合させることによって, 例えば炭素 特有の脆性を改善して勒性の増加などの一層高性能な複合材料 が得られると期待できる。複合化は，(1) 炭素瀻維前駆体への添 加, (2) 母剂炭素前駆体への分散などによって微細組織の変化の 点から検討されている49)。しかしCNTを使用する場合にあって も，母材炭素前駆体への均一分散と炭素繊維間へのそれらの混合 物の均一分散, 炭素瀻維との濡れ性が課題となる。それぞれにつ いて以下にまとめる。

\section{1 炭素織維前駆体へのCNTの添加}

等方性石油系ピッチにSWCNTを $5 \mathrm{wt}$ \%充填したSWCNT 複合 炭素繊維の引張り強度は〜 1.9倍, 引張り弾性率は〜 2.5 倍 (Fig.10, Fig.11), 電気伝導性は4.4倍になった。この複合体中で SWCNT は一方向性の補強材として作用している。母材への均一 分散を図るためにSWCNTを化学修飾して溶解性を上げること ができれば,より高性能炭素瀻維ができるものと考えられる ${ }^{50)} 。$

一方, $0.3 \mathrm{wt} \%$ \% MWCNTを添加したメソフェースピッチ系炭 素瀻維は, 未添加のメソフェースピッチ系炭素繊維に特有の微細 構造としてのラジアル組織がランダムに変化する(Fig.12, Fig.13)。 

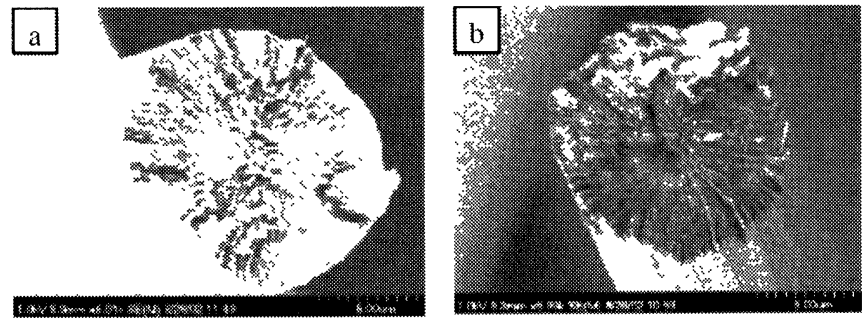

Fig.12 SEM images of carbon fibers produced from pure mesophase pitch melt-spun at $297^{\circ} \mathrm{C}$ (a) and $305^{\circ} \mathrm{C}$ (b) 51).
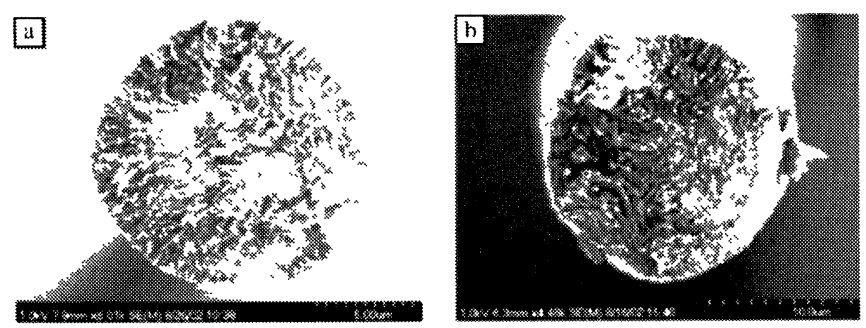

Fig.13 SEM images of carbon fibers produced from mesophase pitch containing different contents of MWCNTs. (a) : 0.1 wt $\%$, (b) : 0.3 wt $\%$ MWCNTs ${ }^{51)}$.

すなわち,ラジアル組織をつくるグラフェン層の配向がMWCNT によってランダム配向になり, MWCNTは明らかに炭素繊維の形 態に影響することがわかった51)。次に, 10wt％のSWCNTを添 加したポリアクリロニトリル (PAN) 複合繊維を酸化安定化処理 したところ, 破断強度は2 倍, 弾性率は 2.6 倍, 酸化複合体繊維の 破断歪みは 2.15 倍になった。また, 破断面はPAN 繊維のみの場 合には広範囲にわたってフィブリルが見られたのに対して, 複合 繊維ではSWCNTの添加量が増えるとフィブリルは減少の傾向 が見られ，母材PAN とSWCNTとの相互作用は強く接着性は良 好であることが示唆された。このことからこの手法を用いれば 高弾性率炭素繊維が製造できるものと期待できる52)。最近, CNT/ $\mathrm{CNF} / \mathrm{CF} / \mathrm{C}$ 複合材料が報告されている。

まず炭素繊維表面を酸化処理し, 次にCVD法でカーボンナノ チューブとナノファイバーを同時に析出させた後, さらに化学気 相浸透法 (CVI) にて緻密化処理を行う。得られたCNT/CNF/CF/C 複合材料では, CNT/CNFの複合部が炭素繊維と母材炭素との間 でブリッジ効果を果たすことで炭素繊維と母材炭素との界面に おける剥離の発達を遅らせるばかりか層間剪断強度の増加につ ながり機械的強化の向上が達成されると期待される53)。

\section{2 母剤炭素前駆体への分散}

熱硬化性樹脂にカーボンブラックや黒鉛粉末を添加して C/C コンポジットを製造する場合には, 収縮によって母材に発生するク ラックがこれらの添加物の存在によって抑制される。また黒鉛 化過程では母材の難黒鉛化性が易黒鉛化性に変化することが知 られている15)。これはバルクな母材炭素の微細構造や性質がナ ノスケールの添加物によって影響を受けたためと考えられる49)。 そこで, 母材炭素前駆体へのCNTの分散は, C/Cコンポジットの

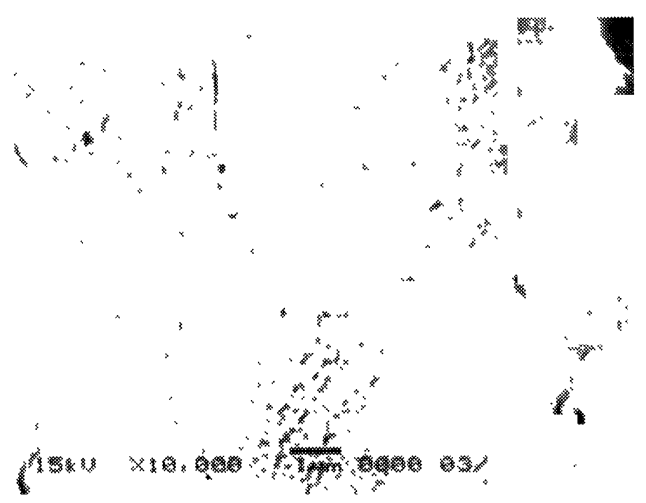

Fig.14 Cross-section of UD-rod C/C composite prepared from $\mathrm{CF} / \mathrm{COPNA}$ resin preform.
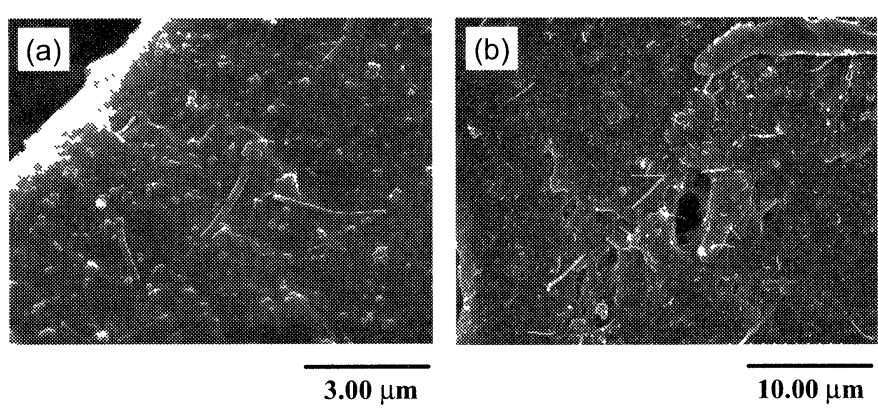

Fig.15 SEM images of the COPNA/CSCNT composites preparerd by (a) ultrasonic processing and (b) kneading.

機械的, 電気的, 熱的性質の改善につながると期待できる。代表 的な手法として, CVI 法と樹脂含浸法の 2 種類を挙げることがで きる。まず炭素繊維表面にCCVD法でCNTを析出させておき， 次にCNTフィラメント間の空隙にCVI法で炭素を浸透させる方

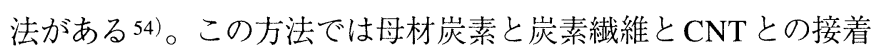
性は強固で結晶性にも優れている。また, CCVD法で一定方向に 整列したCNTを基板上に析出させた後に,そのCNTの隙間にCVI 法でさらに母材炭素を浸透することで約 $0.8 \mathrm{~g} / \mathrm{cm}^{3}$ の低密度でも, 約 $1.50 \mathrm{~g} / \mathrm{cm}^{3}$ の高い密度のC/Cコンポジットよりも $12.31 \%$ 高い 熱伝導性が得られる55)。次にCNTとフェノール樹脂とから作製 したスラリーを, PAN 系炭素繊維とフェノール樹脂とから作製し たC/Cコンポジットに浸透させて炭素化し, CNT/C/C/C コンポジ ットを作製した56)ところ耐磨耗性が向上する傾向を示唆する結 果が得られた。

これまで, 著者らはコールタールピッチを原料とする縮合多環多 核芳香族 (COPNA) 樹脂を母材炭素前駆体として検討してきた。 著者らの最近の結果を以下に述べる。溶媒に溶解したCOPNA 樹脂を炭素繊維 (PAN 系, 東レT-300) に含浸して一方向性の棒 を作製したのち, $1000{ }^{\circ} \mathrm{C} て ゙$ 炭素化処理して C/C コンポジットを作 製した。三点曲げ試験後の試料の破断面をSEMで観察したとこ ろ, Fig.14に示すような結果が観察された57)。炭素繊維と母材炭 素との界面における接着性に着目すると, 炭素繊維のひだの部分 にまで樹脂炭が入り込んでいてCOPNA樹脂は炭素繊維との需れ 性に優れていることがわかる。光学研摩した試料を偏光顕微鏡 
で観察すると, 䋊維と繊維の間に存在する樹脂炭に異方性領域が 観察された。そこで, COPNA樹脂にCNTを混合することでより 炭素繊維の表面処理を行わなくても一層母材炭素の微細組織を 制御できるものと考えられる。Fig.15にCNTとしてヘリングボ ーン構造のカップスタック型CNT (以下CSCNT)を使用したと きのCOPNA/CSCNT コンポジットのSEM像を示す。CSCNTの COPNA 樹脂炭中での分散性は良く, また濡れ性も良いことがわ かる。ヘリングボーン構造をとるCSCNT はチューブラー構造の CNT と比べて活性点が多くて表面が凹凸になるために母材とな る樹脂炭に対してアンカー効果が期待できる。PAN系ならびに ピッチ系炭素繊維とのコンポジットにCSCNTを添加することで 曲げ強度はいずれの炭素繊維を使用した場合でも約 3 倍高い值が 得られている58)。

\section{6. まとめ}

C/Cコンポジットは近年, 製造技術が進んでさまざまなところ で脚光を浴びつつあるが, ナノカーボンもこの十数年で非常に幅広 い分野にわたって展開されている。これらが複合化されたナノ C/Cコンポジットはまだ新しい分野ではあるが, 今後多岐にわた って研究が進んでいくことは間違いないであろう。このときの 興味の対称はCNTのネッキングやうねり構造に代表されるCNT に特有の潜在的な特性の利用であると思われる。従来の C/C コ ンポジットでは緻密化が重要であったが, 熱伝導性などでは密度の 低い状況であっても物性は従来の值を超える成果が得られてお り,コストパーフォーマンスの優れた新しい材料が得られると十 分期待できそうである。しかし, コンポジットの作製においての 技術的な基本原則は母材炭素と補強材, CNT との界面における 接着性の制御にあることがわかる。

今回は触れなかったが, 炭素化処理をしないで母材をポリマー のままで使用する際には界面制御と均一分散に関する報告がか なり見受けられる。今後は, 有機化学的な視点からも捕えていく ことでより一層新しいナノ C/C コンポジットが開発されると予測 される。

\section{文 献}

1) a) 稲垣道夫, 炭素材料工学 (1985) pp.162-174, 日刊工業新聞社 ; b）岩田幸一, 山下幸典, 阪上正剛, 炭素素原料の有効利用 VI (1988) pp.127-139, CPC 研究会.

2）菅原利夫, 工業材料, 47 （No.3）（1999） 59-64.

3) H. W. Kroto, J. R. Heath, S. C. O' Brien, R. F. Curl and R. E. Smalley, Nature 318 (1985) 162-163.

4) S. Iijima, Nature 354 (1991) 56-58.

5) A. Oberlin, M. Endo and T. Koyama, J. Crystal Growth 32 (1976) 335-349.

6) M. Endo, TANSO 2001 [No.200] 202-205 [in Japanese].

7）炭素材料117委員会, “炭素材料中への機能性およびミクロスペース の創製”, 日本学術振興会未来開拓学術研究推進事業研究成果報告 書 (2003).

8) M. Aono, http://www.nanonet.go.jp/japanese/nano/primer/nano12.html

9) V. N. Popov, Mater. Sci. Eng. R. 43 (2004) 61-102.

10）例えば, 経済連意見書, ナノテクが創る未来社会〈n-plan21〉（2001）;
文部科学省ナノテクノロジー総合支援プロジェクト, わかる入門講 座：ナノテクの世界（2002）（詳細は http://www.nanonet.go.jp/ japanese/nano/index.html).

11) B. Maruyama and K. Alam, SAMPE J. 38 (2002) 59-70.

12）a）奥田謙介, 炭素繊維と複合材料（1988）pp.7-8, 共立出版；b）炭 素繊維協会, http://www.carbonfiber.gr.jp/

13） a）大谷杉郎, つくる立場からみた複合材料入門（1995）pp.27-36, 裳華房；b）E. Yasuda and S. Kimura, TANSO 1983［No.115］196208 [in Japanese] ; c) E. Yasuda and Y. Tanabe, Nihon Hukugou Zairyou Gakkaishi 16 (1990) 219-226 [in Japanese] ; d) 炭素緎 維懇話会, 企画・監修, 炭素繊維の応用技術（増補改訂版）（1986） pp.138-150, CMC ; e) J. B. Donnet, S. Rebouillat, J. C. M. Peng and S. K. Ryu, Carbon Fibers (J. B. Donnet, ed.) (1998) pp.486-494, Marcel Dekker Inc., New York ; f) H. Cao, Y. Huang, Z. Zhang and J. Sun, Compos. Sci. Technol. 65 (2005) 1655-1662；g) H. Hatta, K. Goto and T. Aoki, Compos. Sci. Technol. 65 (2005) 2550-2562.

14) a) S. Kimura, E. Yasuda, K. Yasuda, Y. Tanabe, K. Kawamura and M. Inagaki, TANSO 1986 [No.125] 62-68; b) K. Kawamura, S. Kimura, E. Yasuda and M. Inagaki, TANSO 1982 [No.109] 46-52.

15) E. Yasuda, Y. Tanabe, L. M. Manocha and S. Kimura, Carbon 26 (1988) 225-227.

16) S. Kimura, K. Yasuda, E. Yasuda and Y. Tanabe, TANSO 1987 [No.128] 30-37 [in Japanese].

17) S. Kimura, E. Yasuda, H. Tanaka and S. Yamada, Yogyo Kyokaishi 83 (1975) 122-127 [in Japanese].

18）中川隆夫, 炭素素原料の有効利用 VI (1988) pp.96-103, CPC 研究会.

20) L. M. Manocha, E. Yasuda, Y. Tanabe and S. Kimura, Carbon 26 (1988) 333-337.

21) L. M. Manocha, Carbon 32 (1994) 213-223.

22） a）大谷杉郎, 奥田謙介, 松田 滋, 炭素緎維（1983）pp.217-222, 近 代編集社 ； b） J. C. M. Peng, J. B. Donnet, T. K. Wang and S. Rebouillat, Carbon Fibers (J. B. Donnet ed.) (1998) pp.161-229, Marcel Dekker Inc., New York.

23) a) C. Jones and E. Sammann, Carbon 28 (1990) 509-514 ; b) C. Jones and E. Sammann, Carbon 28 (1990) 515-519 ; c) A. Fukunaga, T. Komami, S. Ueda and M. Nagumo, Carbon 37 (1999) $1087-$ 1091 ; d) J. I. Paredes, A. Martinez-Alonso and J. M. D. Tascon, Carbon 40 (2002) 1101-1108 ; e) J. P. Boudou, J. I. Paredes, A. Cuesta, A. Martinez-Alonso and J. M. D. Tascon, Carbon 41 (2003) 41-56 ; f) X. Li and K. Horita, Carbon 38 (2000) 133-138.

24) a) E. Yasuda, Y. Suzuki, Y. Inoue, H. Izawa, O. Ebato, S. Takano, K. Kihara, A. Kondou, M. Ookawa, T. Hiraoka, M. Shimada, M. Kume, K. Niiya, Y. Aiba and K. Takeuchi, TANSO 1995 [No.170] 247-254 [in Japanese] ; b) A. Bismarck, C. Wuertz and J. Springer, Carbon 37 (1999) 1019-1027.

25) a) C. U. Pittman, Jr., G. R. He, B. Wu and S. D. Garner, Carbon 35 (1997) 317-331 ; b) F. Severini, L. Formaro, M. Pegoraro and L. Posca, Carbon 40 (2002) 735-741.

26) C. U. Pittman, Jr., W. Jiang, Z. R. Yue, S. Gardner, L. Wang, H. Toghiani and C. A. L. y. Leon, Carbon 37 (1999) 1797-1807.

27) S. Iijima and T. Ichihashi, Nature 363 (1993) 603-605.

28) H. W. Zhu, C. L. Xu, D. H. Wu, B. Q. Wei, R. Vajtai and P. M. Ajayan, Science 296 (2002) 884-886.

29) M-F Yu, O. Lourie, M. J. Dyer, K. Moloni, T. F. Kelly and R. S. Ruoff, Science 287 (2000) 637-640.

30) a) J. Chen, M. A. Hamon, H. Hu, Y. Chen, A. P. Rao, P. C. Eklund and R. C. Haddon, Science 282 (1998) 95-98 ; b) J. Liu, A. G. Rinzler, H. Dai, J. H. Hafner, R. K. Bradlry, P. J. Boul, A. Lu, T. Iverson, K. Shelinmov, C. B. Huffman, F. R. Macias, Y. S. Shon, T. R. 
Lee, D. T. Colbert and R. E. Smalley, Science 280 (1998) 12531256 ; c) M. A. Hamon, J. Chen, H. Hu, Y. Chen, M. E. Itkis, A. M. Rao and P. C. Haddon, Adv. Mater 11 (1999) 834-840 ; d) M. Sano, A. Kamino, J. Okamura and S. Shinkai, Science 293 (2001) 1299-1301.

31）a）田中一義 編, カーボンナノチューブ ナノデバイスへの挑戦 （2001）化学同人；b）篠原久典 編, ナノカーボンの新展開 世界に 挑む日本の先端技術（2005）化学同人；c） I. Mochida, TANSO 2001 [No.200] 206-216.

32）a）斉藤弥八, 坂東俊治著, カーボンナノチューブの基礎（1998）コ ロナ社；b）特許庁総務部技術調査課, ナノテクノロジーの応用ーカ ーボンナノチューブ, 光半導体走査型プローブ顕微鏡一に関する特 許出願技術動向調査 (2002) など；c) http://www.nanoelectronics.jp/ kaitai/nanotube/basics.htm など; d) S. Maruyama, Houshasen Kagaku 73 (2002) 1-5 [in Japanese] ; e) D. Kasuya and M. Yudasaka, TANSO 2003 [No.207] 87-93 [in Japanese].

33) C. Journet, W. K. Maser, P. Bernier, A. Loiseau, M. Lamy de la Chapelle, S. Lefrant, P. Deniard, R. Lee and J. E. Fischer, Nature 388 (1997) 756-758.

34) Rodriguez-Macias, P. J. Boul, A. H. Lu, D. Heymann, D. T. Colbert, R. S. Lee, J. E. Fischer, A. M. Rao, P. C. Eklund and R. E. Smalley, Appl. Phys. A 67 (1998) 29-37.

35) a) P. Nikolaev, M. J. Bronikowski, R. K. Bradley, F. Rohmund, D. T. Colbert, K. A. Smith and R. E. Smalley, Chem. Phys. Lett. 313 (1999) 91-97 ; b) K. Hata, D. N. Futaba, K. Mizuno, T. Namai, M. Yumura and S. Iijima, Science 306 (2004) 1362-1364; c) S. Maruyama, R. Kojima, Y. Miyauchi, S. Chiashi and M. Kohno, Chem. Phys. Lett. 360 (2002) 229-234.

36) a) Z. F. Ren, Z. P. Huang, D. Z. Wang, J. G. Wen, J. W. Xu, J. H. Wang, L. E. Calvet, J. Chen, J. F. Klemic and M. A. Reed, Appl. Phys. Lett. 75 (1999) 1086-1088 ; b) Z. F. Ren, Z. P. Huang, J. W. Xu, J. H. Wang, P. Bush, M. P. Siegal and P. N. Provencio, Science 282 (1998) 1105-1107 ; c) Z. P. Huang, J. W. Xu, Z. F. Ren, J. H. Wang, M. P. Siegal and P. N. Provencio, Appl. Phys. Lett. 73 (1998) 3845-3847 ; d) Y. H. Tang, Y. F. Zheng, C. S. Lee, N. Wang, S. T. Lee and T. K. Sham, Chem. Phys. Lett. 342 (2001) 259-264.

37) R. T. K. Baker, P. S. Harris, R. B. Thomas and R. J. Waite, J. Catalysis 30 (1973) 86-95.

38) J. Kong, H. T. Soh, A. M. Cassell, C. F. Quate and H. Dai, Nature 395 (1998) 878-881.

39) a) R. Sen, A. Govindaraj and C. N. R. Rao, Chem. Phys. Lett. 267 (1997) $276-280$; b) C. N. R. Rao and R. Sen, Chem. Commun. 15 (1998) 1525-1526； c) H. M. Cheng, F. Li, G. Su, H. Y. Pan, L. L. He, X. Sun and M. S. Dresselhaus, Appl. Phys. Lett. 72 (1998) 32823284 ; d) R. Andrews, D. Jacques, A. M. Rao, F. Derbyshire, D. Qian, X. Fan, E. C. Dickey and J. Chen, Chem. Phys. Lett. 303 (1999) 467-474 ; e) D. C. Li, L. Dai, S. Huang, A. W. H. Mau and Z. L. Wang, Chem. Phys. Lett. 316 (2000) 349-355 ; f) R. Kamalakaran, M. Terrones, T. Seeger, Ph. Kohler-Redlich, M. Rühle, Y. A. Kim, T. Hayashi and M. Endo, Appl. Phys. Lett. 77 (2000) 3385-3387 ; g) A. Cao, L. Ci, D. Li, B. Wei, C. Xu, J. Liang and D. Wu, Chem. Phys. Lett. 335 (2001) 150-154； h) A. Cao, H. Zhu, X. Zhang, X. Li, D. Ruan, C. Xu, B. Wei, J. Liang and D. Wu, Chem. Phys. Lett. 342 (2001) 510-514 ; i) L. F. Sun, Y. Q. Liu, X. C. Ma, Y. Z. Yhong,
S. B. Tang, Y. T. Xiong, D. S. Tang, W. Z. Zhou, X. P. Zou, Y. B. Li, K. L. Tan, S. S. Xie and J. Y. Lin, Chem. Phys. Lett. 340 (2001) $222-226$; j) A. Cao, C. Xu, J. Liang, D. Wu and B. Wei, Chem. Phys. Lett. 344 (2001) 13-17 ; k) H. Hou, A. K. Schaper, F. Weller and A. Greiner, Chem. Mater. 14 (2002) 3990-3994.

40) a) G. Che, B. B. Lakshmi, C. R. Martin, E. R. Fisher and R. S. Ruoff, Chem. Mater. 10 (1998) 260-267； b) T. Kyotani, L. Tsai and A. Tomita, Chem. Mater. 8 (1996) 2109-2113 ; c) N. Wang, Z. K. Tang, G. D. Li and J. S. Chen, Nature 408 (2000) 50-51；d） W. Z. Li, S. S. Xie, L. X. Qian, B. H. Chang, B. S. Zou, W. Y. Zhou, R. A. Zhao and G. Wang, Science 274 (1996) 1701-1703 ; e) W. Li, H. Zhang, C. Wang, Y. Zhang, L. Xu, K. Zhu and S. Xie, Appl. Phys. Lett. 70 (1997) 2684-2686.

41) a) S. Huang, L. Dai and A. W. H. Mau, J. Phys. Chem. B 103 (1999) 4223-4227 ; b) M. Yudasaka, R. Kikuchi, Y. Ohki and S. Yoshimura, Carbon 35 (1997) 195-201.

42) H. Dai, J. H. Hafner, A. G. Rinzler, D. T. Colbert and R. E. Smalley, Nature 384 (1996) 147-150.

43) C. Liu, Y. Y. Fan, M. Liu, H. T. Cong, H. M. Cheng and M. S. Dresselhaus, Science 286 (1999) 1127-1129.

44) G. E. Gadd, M. Blackford, S. Moricca, N. Webb, P. J. Evans, A. M. Smith, G. Jacobsen, S. Leung, A. Day and Q. Hua, Science 277 (1997) 933-936.

45) C. Velasco-Santos, A. L. Martinez-Hernandez, F. T. Fisher, R. Ruoff and V. M. Castano, Chem. Mater. 15 (2003) 4470-4475.

46) a) S. J. Tans, A. R. M. Verschueren and C. Dekker, Nature 393 (1998) 49-52 ; b) S. Frank, P. Poncharal, Z. L. Wang and W. A. de Heer, Science 280 (1998) 1744-1746.

47) W. A. De Heer, W. S. Bacsa, A. Chatelain, T. Gerfin, R. Humphreybaker, L. Forro and L. D. Ugarte, Science 268 (1995) 845.

48）a）林 卓哉, 遠藤守信, 松下卓生, カーボンナノチューブナノデバイ スへの挑戦（田中一義編）（2001）pp.111-117, 化学同人；b）磯部 寛之, 中村, ナノカーボンの新展開（篠原久典 編）（2005）pp.152160, 化学同人.

49) L. M. Manocha, Mater. Sci. Eng. A 412 (2005) 27-30.

50) R. Andrews, D. Jacques, A. M. Rao, T. Rantell, F. Derbyshire, Y. Chen, J. Chen and R. C. Haddon, Appl. Phys. Lett. 75 (1999) 13291331.

51) T. Cho, Y. S. Lee, R. Rao, A. M. Rao, D. D. Edie and A. A. Ogale., Carbon 41 (2003) 1419-1424.

52) B. G. Min, T. V. Sreekumar, T. Uchida and S. Kumar, Carbon 43 (2005) 599-604.

53) Q. M. Gong, Z. Li, X. W. Zhou, J. J. Wu, Y. Wang and J. Liang, Carbon 43 (2005) 2426-2429.

54) F. Cesano, S. Bertarione, D. Scarano and A. Zecchina, Chem. Mater. 17 (2005) 5119-5123.

55) a) Q. M. Gong, Z. Li, D. Li, X. D. Bai and J. Liang, Solid State Commun. 131 (2004) 399-404 ; b) Q. M. Gong, Z. Li, D. Li, X. D. Bai and J. Liang, Mater. Sci. Eng. A 384 (2004) 209-214.

56) D. S. Lim, J. W. An and H. J. Lee, Wear 252 (2002) 512-517.

57）太田道也, 大宮裕美, 日本学術振興会炭素材料 117 委員会第 259 回委 員会資料, 117-259-C-1 (2001).

58）沖野不二雄, 伊藤克博, 東原秀和, 太田道也, 柳澤 隆, 遠藤守信, 日本 学術振興会炭素材料 117 委員会第 274 回資料, 117-273-C-3 (2005). 